\title{
Selective Transgene Expression for Detection and Elimination of Contaminating Carcinoma Cells in Hematopoietic Stem Cell Sources
}

\author{
Ling Chen, Michael Pulsipher, ${ }^{\star}$ Dongshu Chen, Colin Sieff, ${ }^{*}$ Anthony Elias, Howard A. Fine, and Donald W. Kufe \\ Division of Cancer Pharmacology, and *Division of Pediatric Hematology and Oncology, Dana-Farber Cancer Institute, Harvard \\ Medical School, Boston, Massachusetts 02115
}

\begin{abstract}
Tumor contamination of bone marrow (BM) and peripheral blood (PB) may affect the outcome of patients receiving high dose chemotherapy with autologous transplantation of hematopoietic stem cell products. In this report, we demonstrate that replication defective adenoviral vectors containing the cytomegalovirus (CMV) or DF3/MUC1 carcinoma-selective promoter can be used to selectively transduce contaminating carcinoma cells. Adenoviral-mediated reporter gene expression in breast cancer cells was five orders of magnitude higher than that found in $\mathrm{BM}, \mathrm{PB}$, and $\mathrm{CD} 34^{+}$cells. Our results demonstrate that $\mathrm{CD}^{+} 4^{+}$cells have low to undetectable levels of integrins responsible for adenoviral internalization. We show that adenoviral-mediated transduction of a reporter gene can detect one breast cancer cell in $5 \times$ $10^{5} \mathrm{BM}$ or PB cells with a vector containing the DF3/MUC1 promoter. We also show that transduction of the $H S V$-tk gene for selective killing by ganciclovir can be exploited for purging cancer cells from hematopoietic stem cell populations. The selective expression of TK followed by ganciclovir treatment resulted in the elimination of 6-logs of contaminating cancer cells. By contrast, there was little effect on CFU-GM and BFU-E formulation or on long term culture initiating cells. These results indicate that adenoviral vectors with a tumor-selective promoter provide a highly efficient and effective approach for the detection and purging of carcinoma cells in hematopoietic stem cell preparations. (J. Clin. Invest. 1996. 98:2539-2548.) Key words: adenovirus $\bullet$ bone marrow $\bullet$ breast cancer $\bullet$ thymidine kinase $\cdot$ gene therapy
\end{abstract}

Address correspondence to Donald W. Kufe, Division of Cancer Pharmacology, Dana-Farber Cancer Institute, 44 Binney Street, Boston, MA 02115. Phone: 617-632-3141; FAX: 617-632-2934.

Received for publication 29 July 1996 and accepted in revised form 13 September 1996.

1. Abbreviations used in this paper: Ad, adenovirus; $\beta$-gal, $\beta$-galactosidase; BFU-E, erythroid burst-forming unit; BM, bone marrow; $\mathrm{CFU}$ $\mathrm{GM}$, granulocyte-macrophage colony-forming unit; CMV, cytomegalovirus; FDG, fluorescein di- $\beta$-D-galactopyranoside; GCV, ganciclovir; HSV-tk, herpes simplex virus thymidine kinase; LTC-ICs, long-term culture-initiating cells; MOI, multiplicity of infection; PB, peripheral blood; RLU, relative luminescent units; X-gal, 5-bromo-4-chloro-3indolyl $\beta$-D-galactoside.

J. Clin. Invest.

(C) The American Society for Clinical Investigation, Inc.

0021-9738/96/12/2539/10 \$2.00

Volume 98, Number 11, December 1996, 2539-2548

\section{Introduction}

High dose chemotherapy followed by autologous transplantation of bone marrow $(\mathrm{BM})^{1}$ or peripheral blood $(\mathrm{PB})$ as sources of hematopoietic stem cells is being used as a treatment option for patients with breast cancer (1-4). While this approach results in a proportion of patients with prolonged disease-free survival, most patients eventually relapse. One potential explanation for relapse is reinfusion of tumor cells that contaminate the hematopoietic cell preparations (5-7). Immunocytochemistry $(5,8)$, flow cytometry $(8,9)$, and PCR analysis $(10,11)$ have been used to detect contaminating breast cancer cells in BM and PB preparations. Although the significance of breast cancer cell contamination to relapse remains unclear, tumor-free hematopoietic stem cell products for autologous transplantation are nonetheless desirable. In this context, various approaches using mAbs or cytotoxic drugs have been developed for purging of carcinoma cells from BM or PB collections (12-17). These approaches have resulted in the elimination of two to five logs of clonogenic breast cancer cells and varying degrees of toxicity to hematopoietic progenitor and stem cells.

Gene therapy is a potentially novel approach for the purging of carcinoma cells from hematopoietic stem cell preparations. However, efficacy of purging cancer cells will require gene delivery systems which possess a high gene transduction efficiency and target cell specificity. Human adenoviruses are nonenveloped double-stranded DNA viruses which when deleted at the E1 region are replication defective (18). Adenovirus-mediated gene transfer is a highly efficient means of delivering genetic material into a wide spectrum of cells in vitro and in animals. However, in the setting of bone marrow purging, one goal is the selective transduction of exogenous genes into contaminating cancer cells. A potential strategy to achieve such selectivity would be to use a tumor cell specific/selective promoter to direct the expression of a therapeutic gene in the desired target cell. In this context, recent studies have demonstrated that the promoter of the DF3/MUC1 gene can be used to confer selective expression of heterologous genes in breast cancer cells $(19,20)$. DF3/MUC1 antigen is a member of a family of high molecular weight glycoproteins which are aberrantly overexpressed in breast and other carcinomas (21-23). Adenoviral vectors containing the $\beta$-galactosidase or the herpes simplex virus thymidine kinase $(H S V$-tk) gene under control of the DF3 promoter have thus been developed to confer efficient and selective expression of these genes in cancer cells (20).

In the present work, we demonstrate that adenoviral vectors containing the DF3/MUC1 promoter can be used for detection of carcinoma cells in preparations of hematopoietic stem cell sources. The results also demonstrate that selective expression of therapeutic genes in contaminating cancer cells 
is an efficient approach for purging of hematopoietic stem and progenitor cells.

\section{Methods}

Cell lines. The MCF-7, ZR-75-1, BT-20, and SKBR3 breast carcinoma, the A549 lung carcinoma, DU145 prostate carcinoma, SKOV3 ovarian carcinoma, and T98G human glioblastoma cell lines were obtained from American Type Culture Collection (ATCC, Rockville, $\mathrm{MD})$. Cells were grown as monolayers in recommended culture medium supplemented with $10 \%$ heat-inactivated FBS, 2 mM L-glutamine, $100 \mathrm{U} / \mathrm{ml}$ penicillin, and $100 \mu \mathrm{g} / \mathrm{ml}$ streptomycin.

Human hematopoietic cells. Human PB mononuclear cells were isolated by Ficoll-Paque (Pharmacia LKB Biotechnology Inc., Piscataway, NJ) density gradient centrifugation $(d=1.077,400 \mathrm{~g})$ from leukocyte-enriched leukopaks of healthy donors. Cells were suspended in RPMI-1640 medium containing 10\% heat-inactivated FBS, $2 \mathrm{mM}$ L-glutamine, $100 \mathrm{U} / \mathrm{ml}$ penicillin, and $100 \mu \mathrm{g} / \mathrm{ml}$ streptomycin. Bone marrow was obtained from filters used to prepare harvested marrow from normal donors and the mononuclear cells were isolated by Ficoll-Paque density gradient centrifugation. Bone marrow stromal cells were isolated by adherence (24).

CD34 ${ }^{+}$cells were isolated using the Ceprate LC cell separation system (CellPro Inc., Bothell, WA). In brief, BM cells were incubated with a biotinylated mouse anti-CD34 ${ }^{+} \mathrm{mAb}$, washed and then passed through an avidin column. Nonadsorbed cells were removed by washing, and adsorbed cells were eluted from the column. The enriched cells $\left(80-90 \% \mathrm{CD}^{+} 4^{+}\right)$were maintained in Iscove's MEM containing $12.5 \%$ FBS, $12.5 \%$ horse serum, and $1 \mu \mathrm{M}$ hydrocortisone.

Antibody reaction and $F A C S^{\circledast}$ analysis. $\mathrm{mAbs}$ used were specifically reactive with the cell surface antigens: CD3 (T3, Coulter Immunology, Miami, FL), CD13 (L138, Becton Dickinson, San Jose, CA), CD19 (B4, Coulter Immunology), CD34 (Becton Dickinson), CD51 (integrin $\alpha v$, clone 1980; Chemicon Inc., Temecula, CA), integrin $\alpha \nu \beta 3$ (LM609, kindly provided by Dr. David Cheresh, Scripps Research Institute, La Jolla, CA) and integrin $\alpha \nu \beta 5$ (25) (clone B5-IA9, generously provided by Dr. Martin E. Hemler, Dana-Farber Cancer Institute, Boston, MA). Cells were incubated with antibody for 30 min on ice. If the antibody was not directly conjugated with FITC or phycoerythrin (PE), a secondary antibody conjugated with FITC or PE (Sigma Chemical Co., St. Louis, MO) was used for indirect fluorescence labeling. Cells were then washed and evaluated by flow cytometric analysis.

Recombinant adenoviruses (Ad). Ad.CMV-Bgal, Ad.CMV-tk (20), and Ad.CMV-Luc (kindly provided by Dr. Robert Gerard, University of Texas, Austin, TX) (26) are replication-deficient recombinant adenoviruses in which the luciferase, $\beta$-galactosidase, and $H S V$-tk genes, respectively, are under control of the cytomegalovirus (CMV) immediate-early promoter and enhancer. Ad.DF3-ßgal and Ad.DF3-tk are recombinant adenoviruses in which the specified genes are under control of the DF3/MUC1 tumor-selective promoter $(20,27)$. Adenoviral vectors were produced by homologous recombination in the human embryonic kidney cell line 293 as described (28). Large scale production of recombinant adenovirus was accomplished by growth in 293 cells and purification by double cesium gradient ultracentrifugation as described (28). Titers of purified adenovirus were determined by spectrophotometry and by plaque assays.

Adenovirus infection. Cells suspended at 0.5 to $2.0 \times 10^{6} / \mathrm{ml}$ culture medium were infected with adenoviruses at a multiplicity of infection (MOI) of 1 to 1,000 for $2 \mathrm{~h}$, washed, and then resuspended in fresh media. Cells were evaluated for the expression of the transgene at 24 to $48 \mathrm{~h}$ after infection.

Assay for luciferase activity. Luciferase activity was measured with D-luciferin (Analytical Luminescence Laboratory, San Diego, CA) using a luminometer. Activity is presented as relative luminescent units (RLU) in an indicated number of cells.

Assays for $\beta$-galactosidase. (i) Chemiluminescence assay: quantitation of enzyme activity was determined by a chemiluminescence as- say using Galacto-Light system (Tropix, Inc., Bedford, MA) that detects $2 \mathrm{fg}$ to $20 \mathrm{ng}$ of $\beta$-galactosidase (29). Activity is presented as RLU in an indicated number of cells. (ii) Histochemical staining; cells were fixed with $0.5 \%$ glutaraldehyde in PBS containing $1 \mathrm{mM}$ $\mathrm{MgCl}_{2}$ for $10 \mathrm{~min}$, rinsed with PBS, and then incubated with 5-bromo4-chloro-3-indolyl $\beta$-D-galactoside (X-Gal) $(1 \mathrm{mg} / \mathrm{ml}), 5 \mathrm{mM} \mathrm{K}{ }_{3} \mathrm{Fe}$ $(\mathrm{CN})_{6}, 5 \mathrm{mM} \mathrm{K}_{4} \mathrm{Fe}(\mathrm{CN})_{6}, 1 \mathrm{mM} \mathrm{MgCl}_{2}$ in PBS for 4 h. (iii) $\mathrm{FACS}^{\otimes_{-}}$ GAL assay (30): briefly, $0.5-1.0 \times 10^{6}$ cells were suspended in $50 \mu \mathrm{l}$ of serum-free culture medium at $37^{\circ} \mathrm{C}$. An equal volume of $2 \mathrm{mM}$ fluorescein di- $\beta$-D-galactopyranoside (FDG; Molecular Probes, Eugene, OR) was added to each aliquot of cells. The cells and FDG were mixed rapidly and incubated for $1 \mathrm{~min}$ at $37^{\circ} \mathrm{C}$. Thereafter, cells were washed once with $4 \mathrm{ml}$ ice-cold PBS and maintained in ice-cold PBS until analysis.

Tumor cell clonogenic assay. At $24 \mathrm{~h}$ after adenovirus infection, ganciclovir (GCV) was added to cells and incubated for $24 \mathrm{~h}$. Serial dilutions of cells were plated on 30-mm culture dishes. Cells were incubated for $2 \mathrm{wk}$, and colonies ( $>50$ cells) were stained with crystal violet and counted. Results are expressed as the surviving cell fraction \pm SEM for the treated groups compared to controls.

Hematopoietic progenitor cell assays. Erythroid burst-forming units (BFU-E) and granulocyte-monocyte colony-forming units (CFU-GM) were assayed in a methylcellulose culture system (Stem Cell Technologies, Vancouver, Canada) containing recombinant human stem cell factor $(50 \mathrm{ng} / \mathrm{ml}), \mathrm{GM}-\mathrm{CSF}(10 \mathrm{ng} / \mathrm{ml}), \mathrm{IL}-3(10 \mathrm{ng} / \mathrm{ml})$, and erythropoietin (EPO) $(3 \mathrm{U} / \mathrm{ml})$. The numbers of colonies were counted after $2 \mathrm{wk}$. For more primitive progenitor cells, the number of long-term culture-initiating cells (LTC-ICs) were determined by culturing serial dilutions of $\mathrm{CD} 34^{+}$cells on irradiated bone marrow stromal cells in 96-well plates for $5 \mathrm{wk}$. The number of wells that contained colonies was then assessed by growth in methylcellulose culture (Stem Cell Technologies) (24). The frequency of LTC-ICs was calculated by plotting the input cell number against the proportion of negative wells as described $(24,31)$.

PCR analysis. CD34 ${ }^{+}$cells, CFU-GM, and BFU-E picked from methylcellulose culture were digested at $56^{\circ} \mathrm{C}$ for $1-2 \mathrm{~h}$ with proteinase $\mathrm{K}(2 \mathrm{mg} / \mathrm{ml})$ in cell lysis buffer containing $50 \mathrm{mM} \mathrm{KCl}, 10 \mathrm{mM}$ Tris- $\mathrm{HCl}$ ( $\mathrm{pH} 8.3$ ), $1.5 \mathrm{mM} \mathrm{MgCl}, 0.1 \mathrm{mg} / \mathrm{ml}$ gelatin (Sigma Chemical Co.), $0.45 \%$ NP-40, and $0.45 \%$ Tween 20, as described (32). Samples were then heated at $95^{\circ} \mathrm{C}$ for $5 \mathrm{~min}$. DNA was amplified using the GeneAmp PCR reagent kit (Perkin Elmer/Cetus Corp., Norwalk, CT). The $\beta$-actin gene was used as an internal control and amplified using the primers 5'TCACCCACACTGTGCCCAT3' and 5'GCATTTGCGGTGGACGATG3'. The adenovirus E1A gene was amplified using primers 5'ATTACCGAAGAAATGGCCGC3' and 5'CCCATTTAACACGCCATG3'. The adenovirus $E 2 B$ gene was amplified using primers 5'TCGTTTCTCAGCAGCTGTTG3' and 5'CATCTGAACTCAAAGCGTGG3' as described (33).

Statistical analysis. Results are presented as means \pm SEM. Data comparisons were made by ANOVA. Pairwise comparisons were made using Fisher's PLSD (34) with STATVIEW 4.0 software (Abacus Concepts, Inc., Berkeley, CA).

\section{Results}

The efficiency of adenovirus-mediated reporter gene expression was first evaluated in hematopoietic cell preparations using Ad.CMV-Luc and Ad.CMV-ßgal. Luciferase and $\beta$-galactosidase activities were low but detectable in unfractionated $\mathrm{PB}$ and BM mononuclear cells at MOIs of 10 and 100 (Fig. $1 A$ ). By contrast, there was little if any detectable reporter gene expression in these cells when using Ad.DF3- $\beta$ gal (Fig. $1 A$ ). Similar studies in MCF-7 breast cancer cells demonstrated a marked increase in efficiency (five orders of magnitude) of Ad.CMV-Luc and Ad.CMV- $\beta$ gal-mediated reporter gene expression (Fig. 1 B). Moreover, as previously demon- 


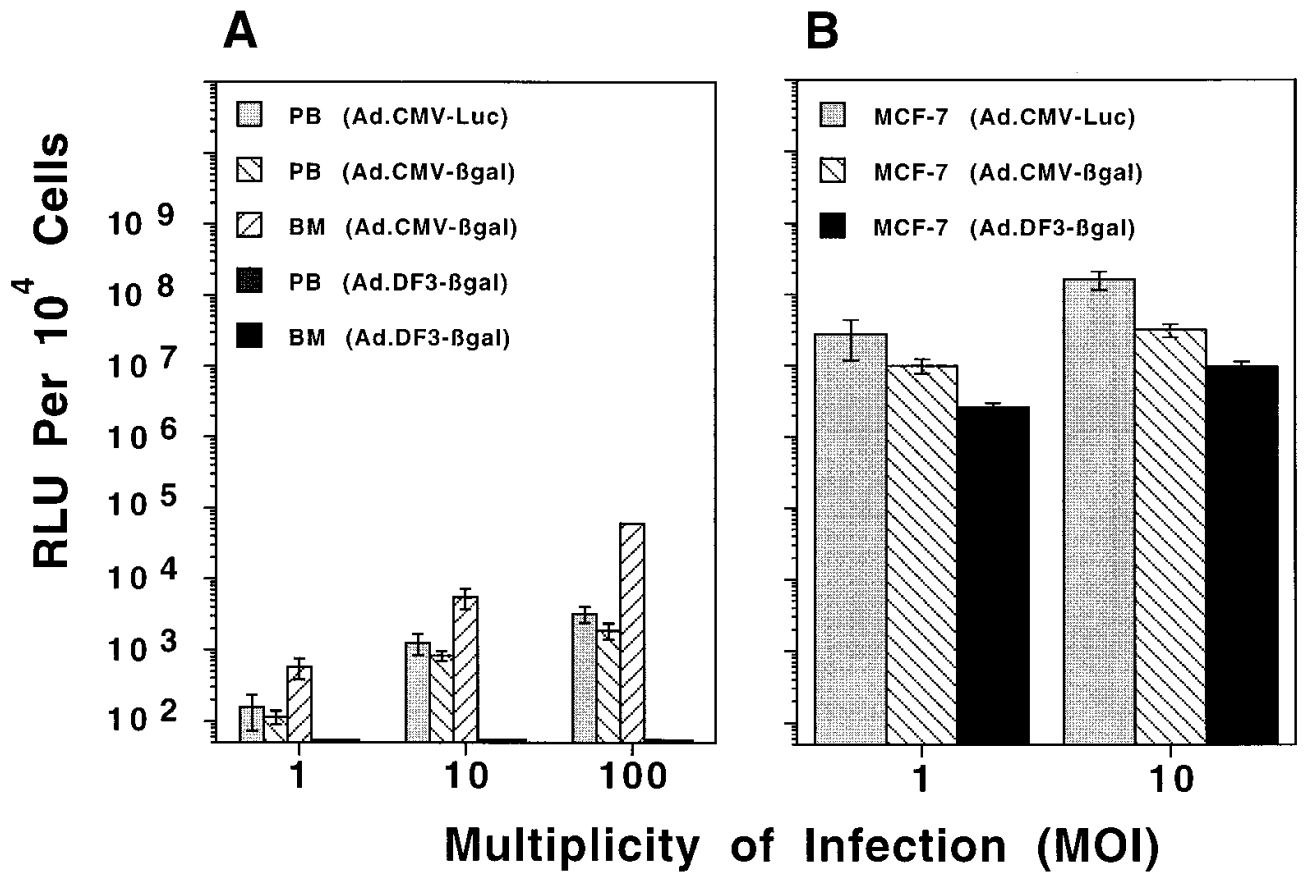

Figure 1. Analysis of adenovirus-mediated reporter gene expression in $\mathrm{PB}, \mathrm{BM}$, and breast cancer cells. $(A) \mathrm{PB}$ and $\mathrm{BM}$ mononuclear cells. $(B)$ MCF-7 breast cancer cells. Cells were infected with Ad.CMV-Luc,

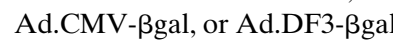
at the indicated MOIs for $2 \mathrm{~h}$ at $37^{\circ} \mathrm{C}$, washed, and cultured for $48 \mathrm{~h}$. Cells were then lysed and assayed for luciferase or $\beta$-galactosidase activity. The results are presented as relative luminescent units $(R L U)$ in the indicated number of cells (mean \pm SEM). Results were obtained from four to nine experiments. strated (20), $\beta$-galactosidase expression was readily detectable

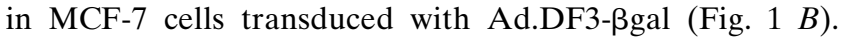
These findings indicated that MCF-7 cells are transduced more efficiently than hematopoietic cells by adenoviral vectors and that the tumor-selective DF3/MUC1 promoter can confer even greater selectivity of transgene expression. Two-color FACS $^{\circledR}$-analysis further indicated that monocytes and macrophages $\left(\mathrm{CD} 14^{+}\right.$cells $)$are the major cell types in PB that express $\beta$-galactosidase when infected with Ad.CMV- $\beta$ gal and not with Ad.DF3-ßgal, while T $\left(\mathrm{CD}^{+}\right)$and $\mathrm{B}\left(\mathrm{CD} 19^{+}\right)$cells
A

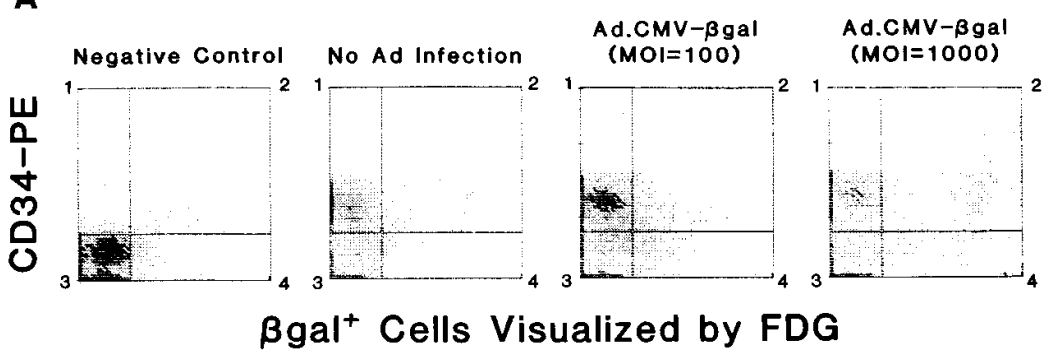

B

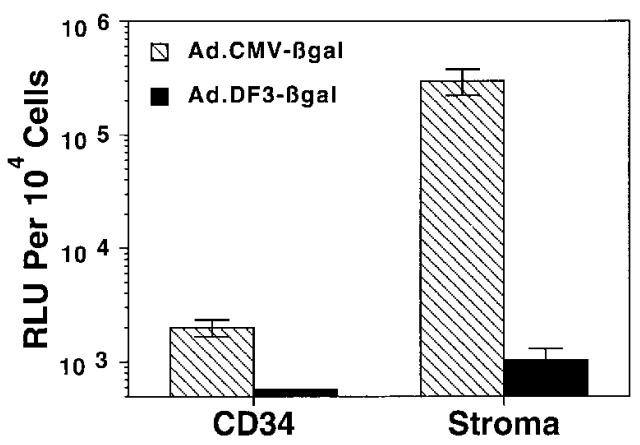

C
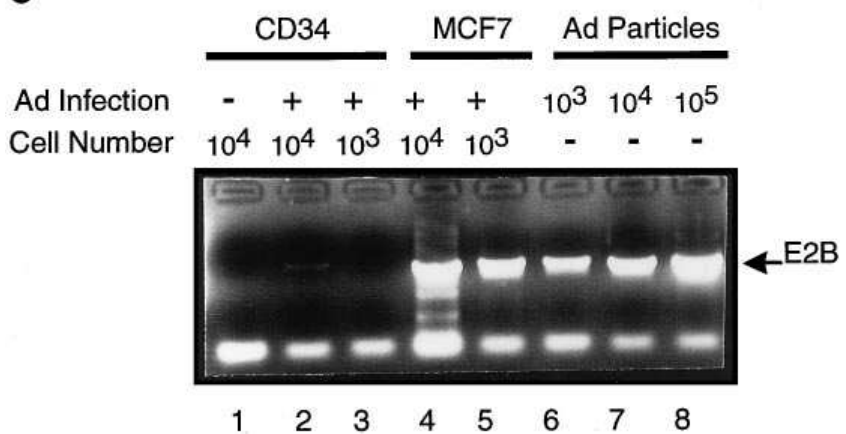

Figure 2. Analysis of adenovirus-mediated gene transfer in $\mathrm{CD}^{+} 4^{+}$ and bone marrow stromal cells. $(A)$ Two-color FACS analysis to detect $\beta$-galactosidase activity in enriched $\mathrm{CD} 34^{+}$cells infected with Ad.CMV- $\beta$ gal or Ad.DF3- $\beta$ gal. At $24 \mathrm{~h}$ after infection, $\mathrm{CD} 34^{+}$cells were stained with PE-conjugated anti-CD34 mAb. Cells expressing $\beta$-galactosidase were visualized by the fluorescence substrate, FDG. (B) $\beta$-galactosidase activity in enriched CD34 cells and bone marrow stromal cells infected with Ad.CMV- $\beta$ gal or Ad.DF3- $\beta$ gal. Cells were infected at a multiplicity of infection $(M O I)$ of 10 for $2 \mathrm{~h}$ at $37^{\circ} \mathrm{C}$, washed, and cultured for $48 \mathrm{~h}$. $\beta$-galactosidase activity was measured by a luminescence assay. The results are presented as relative luminescent units $(R L U)$ in the indicated number of cells (mean \pm SEM for three samples). $(C)$ Determination of adenoviral DNA in adenovirusinfected $\mathrm{CD} 4^{+}$and MCF-7 cells. Cells were infected with adenovirus $(\mathrm{MOI}=10)$ at $37^{\circ} \mathrm{C}$ for $2 \mathrm{~h}$. Cells were incubated with trypsin/EDTA solution at $37^{\circ} \mathrm{C}$ for $5 \mathrm{~min}$ and washed three times with medium. DNA extracted from $10^{4}$ (lanes 2 and 4 ) and $10^{3}$ (lanes 3 and 5) fluorescencesorted CD $34^{+}$cells or MCF-7 cells infected with adenovirus were used for PCR amplification ( 25 cycles) of a 0.86 kb sequence in the adenoviral E2B gene. Adenoviral DNA equivalent to $10^{3}, 10^{4}$, and $10^{5}$ pfu was used as a reference control. 
express little if any transgene with either vector (data not shown).

To determine if adenovirus mediates transgene expression in $\mathrm{CD}_{3} 4^{+}$hematopoietic stem and progenitor cells, we performed two-color FACS ${ }^{\circledR}$ analysis of enriched $\mathrm{CD}^{+} 4^{+}$cells infected with Ad.CMV-ßgal. At a MOI of $100,<4 \%$ of CD $34^{+}$ cells expressed the transgene, while $\sim 11 \%$ of the $\mathrm{CD}^{+} 4^{+}$cells were $\beta$ gal positive at a MOI of 1,000 (Fig. $2 A$ ). These findings indicated that transduction of $\mathrm{CD}_{3} 4^{+}$cells is inefficient compared with that for MCF-7 cells. A sensitive chemiluminescent assay showed that there was little $\beta$-galactosidase expression when enriched $\mathrm{CD} 34^{+}$cells were transduced with Ad.CMV$\beta$ gal $\left(\sim 2,000 \mathrm{RLU} / 10^{4}\right.$ cells at a MOI $\left.=10\right)$ and no $\beta$-galactosidase expression with Ad.DF3-ßgal (Fig. 2 B). By contrast to the $\mathrm{CD}_{34}{ }^{+}$cells, bone marrow stromal cells were transduced efficiently by Ad.CMV- $\beta$ gal $\left(10^{6} \mathrm{RLU} / 10^{4}\right.$ cells at a MOI $\left.=10\right)$ (Fig. 2 B). Moreover, the stromal cells exhibited little $\beta$-galactosidase expression after transduction with Ad.DF3-ßgal (Fig. $2 \mathrm{~B}$ ). To substantiate the relatively low infectability of CD $34^{+}$ cells by adenovirus, we used PCR to determine the relative copy number of virus per cell after infection. Purified bright $\mathrm{CD} 4^{+}$cells infected with adenovirus were obtained by fluorescence sorting and DNA was extracted for PCR analysis of adenoviral E2B sequences. There was no detectable adenovirus in $10^{3} \mathrm{CD}^{2} 4^{+}$cells infected at a MOI of 10 , while the E2B signal was readily apparent from $10^{3}$ transduced MCF-7 cells (Fig. $2 \mathrm{C}$ ). A low level signal was obtained when assaying $10^{4}$ infected CD $34^{+}$cells (Fig. 2 C). By comparison with an adenovirus standard, we estimate that there are $\sim 10$ copies of virus per MCF-7 cell and $<0.01$ copy per $\mathrm{CD} 34^{+}$cell when cells were infected with adenovirus at a MOI of 10.

Adenovirus infection is a two-step process involving the initial attachment of adenoviral fiber protein to a relatively ubiquitously expressed, but yet unidentified, receptor and then internalization through interaction of the adenoviral penton base with $\alpha \nu$ integrins, particularly $\alpha \nu \beta 3$ and $\alpha \nu \beta 5$ heterodimers $(35,36)$. FACS ${ }^{\circledR}$ analysis indicated that $\mathrm{CD}^{+} 4^{+}$cells had no detectable $\alpha \nu$ subunits, $\alpha \nu \beta 3$, or $\alpha \nu \beta 5$ (Table I). By contrast, $\alpha \nu$ subunits were strongly expressed on breast cancer, lung cancer, prostate cancer, and glioblastoma cells (Table I). The tumor cells expressed $\alpha \nu \beta 5$ at high levels and $\alpha \nu \beta 3$ to a lesser extent (Table I). These results indicated that the low

Table I. FACS Analysis of Integrin $\alpha \nu$ Subunit and $\alpha \nu \beta 3, \alpha \nu \beta 5$ Heterodimers in $\mathrm{CD}_{3} 4^{+}$Cells and Carcinoma Cells

\begin{tabular}{llccc}
\hline \multicolumn{1}{c}{ Cell } & \multicolumn{1}{c}{ Type } & $\alpha \nu$ & $\alpha \nu \beta 3$ & $\alpha \nu \beta 5$ \\
\hline CD34 $^{+}$ & Hematopoietic progenitor cells & - & - & - \\
MCF-7 & Breast cancer & ++++ & - & +++ \\
BT-20 & Breast cancer & ++++ & - & ++++ \\
ZR-75 & Breast cancer & ++++ & - & +++ \\
SKBR3 & Breast cancer & ++++ & - & +++ \\
A549 & Lung cancer & ++++ & + & +++ \\
DU145 & Prostate cancer & ++++ & ++ & +++ \\
T98G & Brain glioblastoma & ++++ & ++ & +++ \\
& & & & \\
\hline
\end{tabular}

Cells were stained with $\mathrm{mAbs}$ for $\alpha \nu$ subunit, $\alpha \nu \beta 3$, and $\alpha \nu \beta 5$ heterodimers as described in Methods. Quantitation was determined as described (25) on the basis of fluorescence intensity. ++++ , values above 60 ; +++ , between 30 and $60 ;++$, between 10 and $30 ;+$, values between 5 and $10 ;-$, values under 5 .
Table II. Adenovirus-mediated Reporter Gene Expression in Breast Cancer Cells Premixed with PB Mononuclear Cells

\begin{tabular}{lccc}
\hline & \multicolumn{3}{c}{ RLU per $10^{5}$ cells $($ mean \pm SEM) } \\
\cline { 2 - 4 } Mer $10^{6}$ PB & Ad.CMV-Luc & Ad.CMV- $\beta$ gal & Ad.DF3- $\beta$ gal \\
\hline 0 & $1.1 \pm 0.2 \times 10^{4}$ & $2.1 \pm 0.7 \times 10^{3}$ & $0.5 \pm 0.3 \times 10^{2}$ \\
& $(1)$ & $(1)$ & $(1)$ \\
2 & $2.4 \pm 1.7 \times 10^{4}$ & $3.5 \pm 0.4 \times 10^{3}$ & $2.0 \pm 0.8 \times 10^{2}$ \\
& $(2.3)$ & $(1.6)$ & $(4.0)^{*}$ \\
10 & $1.0 \pm 0.4 \times 10^{5}$ & $9.9 \pm 5.7 \times 10^{3}$ & $1.4 \pm 0.4 \times 10^{3}$ \\
& $(10)^{*}$ & $(5)^{*}$ & $(28)^{*}$ \\
$10^{2}$ & $8.7 \pm 6.1 \times 10^{5}$ & $4.9 \pm 3.4 \times 10^{4}$ & $4.4 \pm 0.8 \times 10^{3}$ \\
& $(83)^{\ddagger}$ & $(23)^{*}$ & $(90)^{\ddagger}$ \\
$10^{3}$ & $6.4 \pm 1.9 \times 10^{4}$ & $1.4 \pm 0.5 \times 10^{5}$ & $1.2 \pm 0.9 \times 10^{5}$ \\
& $(615)^{\ddagger}$ & $(172)^{\ddagger}$ & $(2,359)^{\ddagger}$ \\
$10^{4}$ & $3.2 \pm 1.7 \times 10^{7}$ & $5.0 \pm 4.0 \times 10^{6}$ & $0.6 \pm 0.3 \times 10^{6}$ \\
& $(5,947)^{\ddagger}$ & $(2,354)^{\ddagger}$ & $(11,843)^{\ddagger}$ \\
& & & \\
\hline
\end{tabular}

MCF-7 cells were premixed with PB cells at the indicated ratios. The cells were incubated with Ad.CMV-Luc, Ad.CMV- $\beta$ gal, and Ad.DF3$\beta g a l$ at a MOI of 10 for $2 \mathrm{~h}$ at $37^{\circ} \mathrm{C}$. At $48 \mathrm{~h}$ after infection, cells were harvested, lysed, and assayed for reporter activities using a luminometer. The reporter activities are presented as RLU per 100,000 cells (mean \pm SEM) obtained from four experiments. A background value of RLU from the uninfected cells was subtracted. The fold increase of reporter activity relative to tumor-free PB cells $(\mathrm{MCF}-7=0)$ is in parentheses $\left({ }^{*} P \leq 0.05 ;{ }^{\ddagger} P \leq 0.001\right)$.

level of adenoviral-mediated transduction in $\mathrm{CD}^{+} 4^{+}$, as compared to carcinoma, cells is attributable at least in part to the absence of integrins that contribute to adenoviral internalization.

The finding that adenovirus preferentially transduces carcinoma, as compared to hematopoietic, cells suggested that adenoviral-mediated reporter gene expression could be used to detect contaminating cancer cells in PB and BM. To address this issue, MCF-7 cells were premixed with $\mathrm{PB}$ cells at ratios of $1: 10^{2}$ to $2: 10^{6}$. Reporter activity of Ad.CMV-Luc- and Ad.CMV-ßgal-infected cell mixtures reflected the number of contaminating MCF-7 cells (Table II). The level of luciferase activity mediated by Ad.CMV-Luc infection was significantly increased at a ratio of $10 \mathrm{MCF}-7$ cell $/ 5 \times 10^{5} \mathrm{~PB}$ mononuclear cells. Higher ratios were associated with increases in reporter gene expression (Table II). Similar results were obtained with Ad.CMV-ßgal (Table II). Studies performed with Ad.DF3Bgal demonstrated a lower background with uncontaminated $\mathrm{PB}$ mononuclear cells and enhanced sensitivity with detection of one MCF-7 cell/5 $\times 10^{5} \mathrm{~PB}$ cells (Table II). Similar results were obtained with Ad.DF3-ßggal when ZR-75-1 breast cancer cells were mixed with PB cells (data not shown). Other studies were performed on BM cells that had been contaminated $(0.1 \%)$ with DF3/MUC1-positive breast, lung, prostate, and ovarian cancer cells. The contaminated BM cells demonstrated a marked elevation in reporter activity when using Ad.DF3Bgal (Fig. $3 A$ ). Furthermore, contamination of $\mathrm{BM}$ with increasing numbers of MCF-7 cells resulted in higher levels of Ad.DF3- $\beta$ gal-mediated reporter gene expression, while there was no increase in $\beta$-galactosidase expression when the BM cells were contaminated with DF3/MUC1 negative T98G glioblastoma cells (Fig. 3 B). 
A

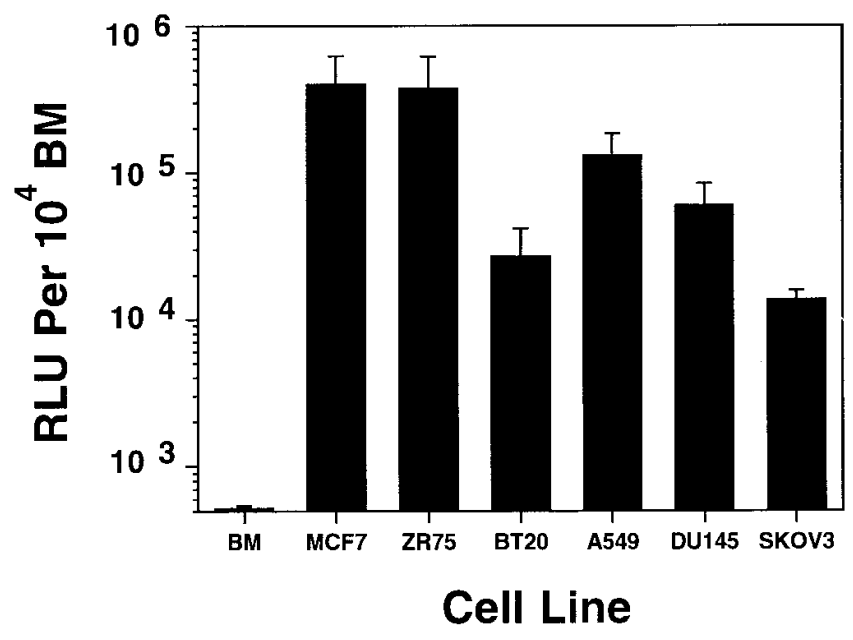

B

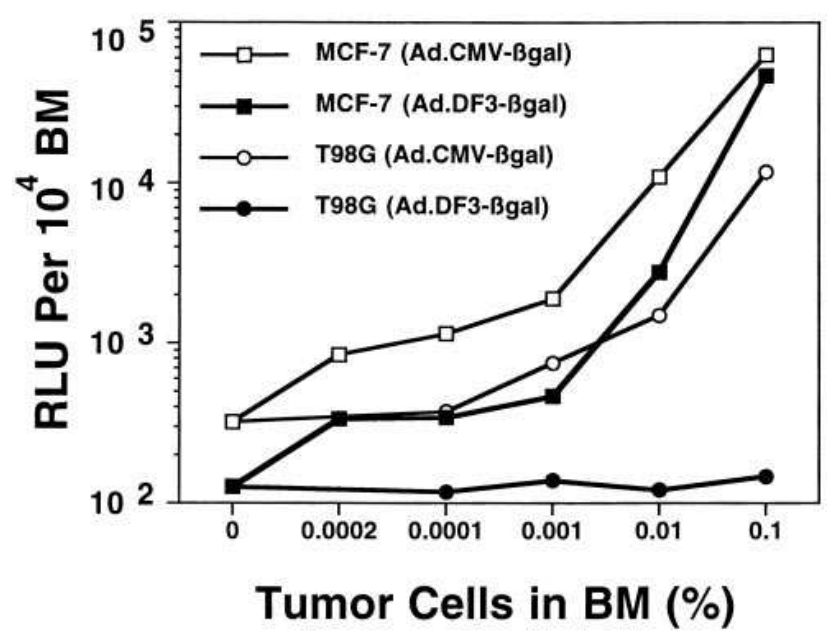

Figure 3. Adenovirus-mediated reporter gene expression in BM contaminated with cancer cells. (A) BM mononuclear cells were mixed with $0.1 \%$ MCF-7, ZR-75, BT-20 (breast cancer), A549 (lung cancer), DU145 (prostate cancer), and SKOV3 (ovarian cancer) cells. The cells were incubated with Ad.DF3- $\beta$ gal at a MOI of 10 for $2 \mathrm{~h}$ at $37^{\circ} \mathrm{C}$. After $24 \mathrm{~h}$, cells were lysed and assayed for reporter gene expression by chemiluminescence assay. (B) BM mononuclear cells premixed with various ratios of MCF-7 or T98G cells were incubated with either Ad.CMV- $\beta$ gal or Ad.DF3- $\beta$ gal at a MOI of 1 for $2 \mathrm{~h}$ at $37^{\circ} \mathrm{C}$, washed, and cultured for $24 \mathrm{~h}$. $\beta$-galactosidase expression was measured by chemiluminescence assay. Similar results were obtained in three separate experiments.

To extend the observation of selective adenoviral-mediated reporter gene expression, we explored other approaches for detection of contaminating carcinoma cells. BM mononuclear cells with and without contaminating MCF-7 cells were infected with Ad.DF3- $\beta$ gal and then visualized for X-gal staining. Using this approach, the MCF-7 cells could be readily identified by blue staining (Fig. $4, A$ and $B$ ). The contaminating cells were also readily apparent by fluorescence micros- copy after staining with the fluorescence substrate FDG (Fig. 4, $C$ and $D$ ). Cells that expressed $\beta$-galactosidase also reacted with mAb DF3 (data not shown), a monoclonal antibody that detects DF3/MUC1 (21). These findings indicated that histochemical, as well as biochemical, approaches can be used for detection of contaminating tumor cells by adenoviral-mediated reporter gene expression.

The selectivity of adenoviral-mediated gene transduction for contaminating tumor cells supported the possibility of using this approach to purge hematopoietic cell populations. Previous studies have documented the strategy of expressing the $H S V$ - $t k$ gene for selective killing by GCV (20). To exploit this strategy for purging, adenovirus carrying HSV-tk under control of the CMV or DF3/MUC1 promoters was used to transduce PB cells premixed with tumor cells. As determined by clonogenic survival, infection at an MOI of 10 followed by GCV treatment (10 to $1,000 \mu \mathrm{M})$ resulted in the elimination of over $6 \operatorname{logs}$ of contaminating MCF-7 cells. Infection with Ad.DF3-tk at a MOI of 100 and then treatment with $100 \mu \mathrm{M}$ GCV killed $\sim 6$ logs of cancer cells (Fig. $5 A$ ). In addition, this approach effectively eliminated other contaminating breast, prostate, lung, and glioblastoma tumor cells premixed with BM cells (Fig. 5 B).

A potential adverse effect of ex vivo purging is toxicity to hematopoietic progenitor cells. We thus assessed the effects of adenoviral infection and GCV treatment on CFU-GM and BFU-E. Infection with Ad.CMV-tk or Ad.DF3-tk at a MOI of 10 followed by GCV $(100 \mu \mathrm{M})$ treatment had little effect on CFU-GM and BFU-E as compared with GCV alone $(\leq 10 \%$ cytotoxicity). Adenovirus infection alone at a MOI of $10 \mathrm{had}$ little if any effect on colony formation (Table III). At a MOI of 100 , there was a $17-19 \%$ decrease in BFU-E and CFU-GM when Ad.CMV-tk and GCV were used, while there was less of an effect with Ad.DF3-tk and GCV (Table III). Limiting dilution assays were also performed on enriched $\mathrm{CD} 34^{+}$cells to assess the effects of adenovirus and GCV treatment on LTC-ICs. The results demonstrate that infection with Ad.CMV-tk with or without GCV treatment has little if any effect on the regeneration and differentiation of the primitive progenitor cells

Table III. Progenitor Cell Growth of $\mathrm{CD}_{34}{ }^{+}$Cells Treated with Adenovirus and $G C V$

\begin{tabular}{lcc}
\hline \multicolumn{1}{c}{ Treatment } & BFU-E & CFU-GM \\
\hline Untreated & 100 & 100 \\
+ GCV & $91 \pm 2.8^{*}$ & $90 \pm 2.5^{*}$ \\
+ Ad.DF3-tk $(\mathrm{MOI}=10)$ & $102 \pm 4.1$ & $100 \pm 3.2$ \\
+ Ad.DF3-tk $(\mathrm{MOI}=10)+\mathrm{GCV}$ & $91 \pm 3.9$ & $91 \pm 2.8^{*}$ \\
+ Ad.DF3-tk $(\mathrm{MOI}=100)+\mathrm{GCV}$ & $90 \pm 3.3^{*}$ & $90 \pm 3.0^{*}$ \\
+ Ad.CMV-tk $(\mathrm{MOI}=10)$ & $100 \pm 3.2$ & $100 \pm 3.1$ \\
+ Ad.CMV-tk $(\mathrm{MOI}=10)+\mathrm{GCV}$ & $90 \pm 3.0^{*}$ & $89 \pm 3.0^{*}$ \\
+ Ad.CMV-tk $(\mathrm{MOI}=100)+\mathrm{GCV}$ & $83 \pm 3.9^{\ddagger}$ & $81 \pm 4.0^{\ddagger}$
\end{tabular}

Enriched $\mathrm{CD} 34^{+}$cells were treated with the indicated adenovirus for $24 \mathrm{~h}$ at $37^{\circ} \mathrm{C}$, washed, and cultured for $24 \mathrm{~h}$. GCV $(100 \mu \mathrm{M})$ was then added for $24 \mathrm{~h}$. The cells were washed and then cultured in methylcellulose for $2 \mathrm{wk}$. The number of colonies in the treated groups is expressed as the percentage (mean \pm SEM from four experiments) of that for untreated controls $(21.8 \pm 7.3 \mathrm{BFU}-\mathrm{E}$ and $26 \pm 5.9 \mathrm{CFU}-\mathrm{GM}$ per 1,000 CD34 ${ }^{+}$cells). ${ }^{*} P \leq 0.05,{ }^{\ddagger} P \leq 0.001$ vs untreated control; ${ }^{\circledR} P \leq 0.05$ vs $\mathrm{GCV}$ alone. 


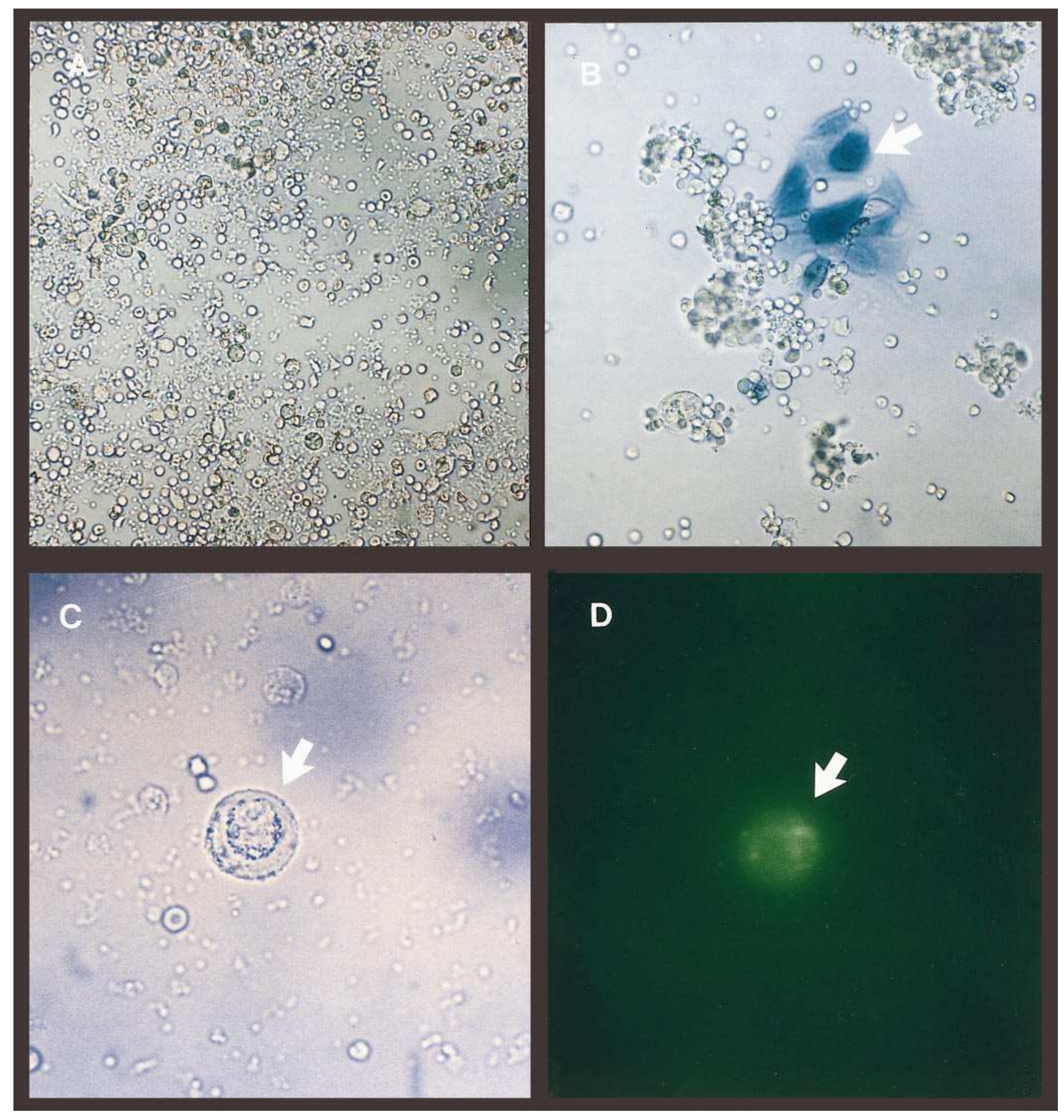

Figure 4. Detection of contaminating breast cancer cells in BM by Ad.DF3- $\beta$ gal. Cells were incubated with Ad.DF3- $\beta$ gal $(\mathrm{MOI}=10)$ for $2 \mathrm{~h}$ at $37^{\circ} \mathrm{C}$, washed, cultured for $24 \mathrm{~h}$, fixed and then stained with X-gal. $(A) \mathrm{BM}$ mononuclear cells without MCF-7 cells. $(B) \mathrm{BM}$ mononuclear cells containing $0.1 \%$ MCF-7 cells. Magnification is 400. Cells were also incubated with FDG and observed under a fluorescent microscope. $(C)$ Bright field. (D) Dark field. Magnification is 1000. Arrows indicate breast cancer cells.

(Fig. 6). Additional experiments were performed to determine if adenovirus is detectable in the progeny cells after adenoviral purging of progenitor cells. CFU-GMs and BFU-Es were picked from methycellulose and cultured with 293 cells. No live adenovirus was rescued in three separate experiments. Reverse transcription PCR analysis of CFU-GM and BFU-E colonies failed to detect any transgene expression mediated by recombinant adenovirus (data not shown). Importantly, the finding that PCR analysis did not detect the presence of adenoviral E1a sequences indicated no wild-type adenovirus replication.

\section{Discussion}

A major issue for autologous $\mathrm{BM}$ or $\mathrm{PB}$ transplantation in breast cancer patients is the potential risk of collecting and re- 


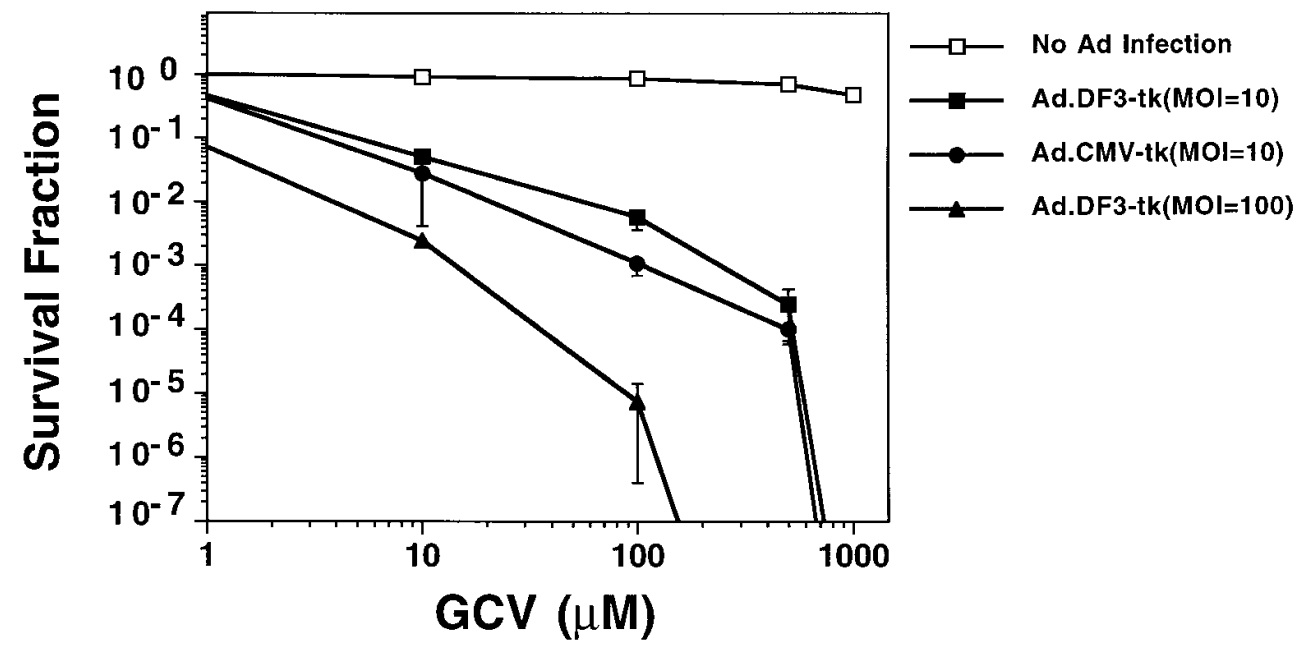

B

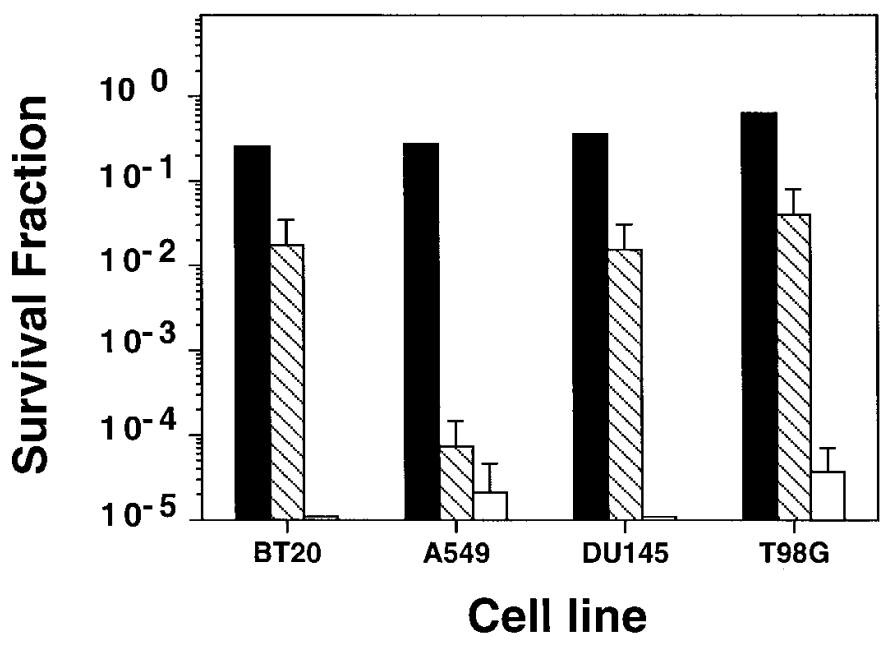

infusing tumor cells. In this context, a study using histochemical detection has demonstrated BM involvement in $50 \%$ of patients with localized breast cancers and both BM (70\%) and PB (22.5\%) involvement in patients with stage IV disease (5). Gene transfer may provide one strategy for improving the detection and purging of tumor cells in BM or PB preparations. However, the presently available gene delivery systems generally lack target cell specificity. Ligand-DNA complexes, DNAliposome complexes, and direct transfer of DNA are limited by a low efficiency of gene transduction (37-40). Moreover, the use of retroviral vectors for detection or purging of cancer cells in hematopoietic stem cell preparations could be limited by dependence on replication of the target cell. By contrast, replication-defective adenoviral vectors represent a highly efficient approach for in vitro gene transfer. One potential limitation of this vector system could be transduction of reporter or therapeutic genes into hematopoietic as well as tumor cells. However, the present studies demonstrate that adenovirus is
Figure 5. Effects of Ad.CMV-tk and Ad.DF3-tk infection followed by GCV treatment on the survival of cancer cells premixed in $\mathrm{PB}$ or $\mathrm{BM}$ mononuclear cells. Cancer cells were premixed with 10-fold excess of irradiated PB or BM cells. The cells were then incubated with recombinant adenoviruses at $37^{\circ} \mathrm{C}$ for $2 \mathrm{~h}$. At $24 \mathrm{~h}$ after infection, cells were treated with $\mathrm{GCV}$ at the indicated concentrations for $24 \mathrm{~h}$, and were then replated on 30-mm plates in duplicate at serial dilutions ranging from 500 to $10^{6}$ cells per well. 2 wk later, the number of colonies $(>50$ cells) was assessed by crystal violet staining. (A) Clonogenic assay for MCF-7 breast cancer cells premixed in PB and infected with Ad.CMV-tk or Ad.DF3-tk at the indicated MOIs followed by GCV treatment. The results are expressed as survival fraction, i.e., colony numbers in plates treated with adenovirus and/or GCV as a fraction of that for untreated controls (mean \pm SEM for two to four experiments). (B) Clonogenic assay for carcinoma cells premixed in BM treated with Ad.CMV-tk at a MOI of 10 and GCV. markedly inefficient in the transduction of BM and PB, as compared with carcinoma, cells. Importantly, transduction of purified $\mathrm{CD}^{+} 4^{+}$hematopoietic stem and progenitor cells is also inefficient compared with that of cancer cells. Another study has recently reported similar results in BM and CD34 cell preparations (41). Our results further indicate that the CD $34^{+}$cell populations express low to undetectable levels of the $\alpha \nu \beta 3$ and $\alpha \nu \beta 5$ integrins. Internalization of adenovirus requires interaction of the adenoviral penton base with $\alpha v$ integrins $(35,36)$. Consequently, the absence of detectable $\alpha \nu$ integrin subunits on $\mathrm{CD}_{3} 4^{+}$cells and their high level expression on diverse cancer cells provides a mechanistic explanation for the selectivity of transduction.

The finding that adenoviral-mediated gene transduction is inefficient in BM and PB cell preparations compared to carcinoma cells supported the potential for using this approach to detect contaminating tumor cells. Transduction of the luciferase or $\beta$-galactosidase genes demonstrated a correlation 

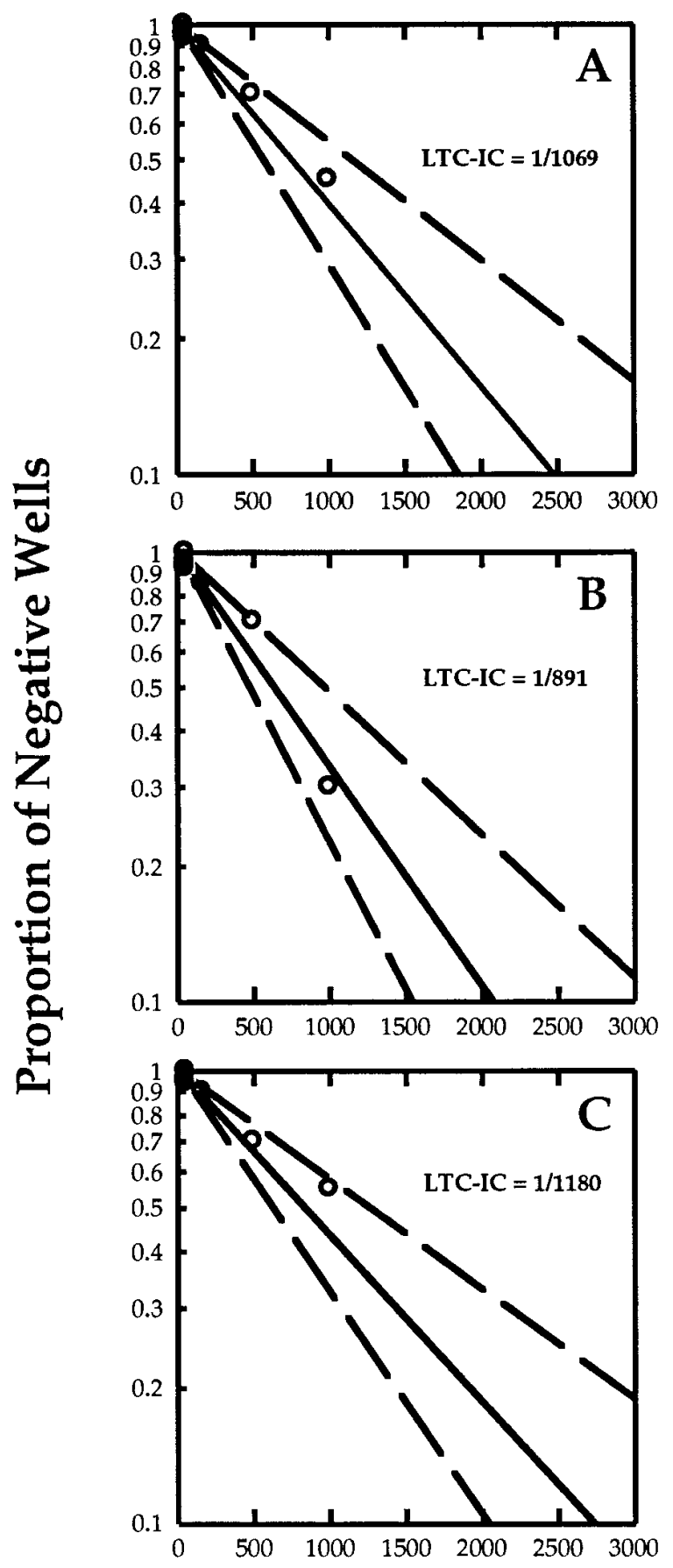

\section{Cell Number}

Figure 6. Limiting dilution analysis of LTC-ICs for primitive progenitor cells. Enriched CD $34^{+}$cells were treated as described in Table III, and seeded onto irradiated marrow feeders in 96-well plates at concentrations of 55 to 4,000 cells/well and 20 wells per concentration. The number of clonogenic wells was assessed after $5 \mathrm{wk}$ of suspension culture and $2 \mathrm{wk}$ of growth in methylcellulose. The frequency of LTC-ICs was calculated by plotting the input cell number against the proportion of negative wells. The best linear fit and standard errors were determined from the data. $(A)$ Untreated control. $(B)$ Ad.CMV-tk infection (MOI = 10). $(C)$ Ad.CMV-tk $(M O I=10)$ and GCV $(100 \mu \mathrm{M})$ treatment. Similar results were obtained in two independent experiments. between reporter expression and the number of contaminating cells. Expression of the reporter resulted in the detection of one cancer cell in $5 \times 10^{5} \mathrm{BM}$ or PB cells. By contrast, an immunohistochemical method using antibodies against cytokeratin detects one tumor cell in $4 \times 10^{5} \mathrm{BM}$ cells (5). Moreover, we found that Ad.DF3-ßgal transduction can be adapted for histochemical detection and thereby morphological examination by staining with X-gal or FDG. Furthermore, the use of the tumor-selective promoter resulted in lower backgrounds with uncontaminated hematopoietic cell preparations. We previously demonstrated that use of the DF3 promoter in adenoviral vectors provides an efficient and selective approach to target expression of heterologous genes in breast cancer cells (20). There are presently several other tumor-specific or selective promoter sequences that have been used to confer selective expression of heterologous genes in tumor cells (42-45). The present results suggest that use of a tumor-selective promoter in the context of an adenoviral vector can provide a highly sensitive approach for the detection of cancer cells in hematopoietic cell preparations. Studies will now be needed that directly compare the sensitivity of the present approach with other techniques used for detection of contaminating carcinoma cells.

The differential sensitivity of hematopoietic as compared to carcinoma cell transduction by adenoviral vectors further supported the use of this approach to purge contaminating tumor cells. Previous studies have demonstrated that purging $\mathrm{BM}$ preparations with 4-hydroperoxycyclophosphamide (4-HC) can lead to 2-3 logs of tumor cell depletion $(12,17)$. The use of immunomagnetic separation in combination with 4-HC eliminated up to 5 logs of tumor cells (12). However, this approach significantly reduced the recovery of CFU-GM (12). mAbs linked with toxin proteins have also been used for in vitro purging of bone marrow. mAb DF3 linked to ricin resulted in the elimination of 2-3 logs of breast tumor cells (13). However, this approach also resulted in the reduction of CFU-GM formation. The present studies demonstrate that adenoviral mediated gene transduction using Ad.DF3-tk and GCV treatment results in the elimination of $6 \mathrm{logs}$ of contaminating breast cancer cells. Importantly, there was little effect of Ad.DF3-tk transduction and GCV treatment on recovery of CFU-GM and BFU-E. Moreover, the adenovirus-mediated transduction of thymidine kinase to confer GCV sensitivity had little effect on LTC-ICs of enriched CD $34^{+}$cells. Since completion of the present studies, another report has demonstrated that adenoviral vectors expressing wild type p53 can be used to purge breast cancer cells mixed with normal bone marrow (41). Other studies have demonstrated that adenoviruses can be used to selectively transduce cancer cells with genes that induce apoptosis (46) and to increase transduction of plasmid vectors coding for toxin genes (41). Thus, combining several adenoviral-mediated strategies could be useful in increasing the efficacy of purging contaminating cancer cells in hematopoietic cell preparations.

Finally, the present results suggest that adenoviral-mediated gene transduction could be useful for the detection and elimination of diverse carcinomas contaminating bone marrow and peripheral blood collections. In addition to studies with breast cancer cells, adenoviral-mediated transduction was highly efficient for cells derived from lung, prostate, and ovarian carcinomas. As the DF3/MUC1 antigen is overexpressed in breast, lung, prostate, and ovarian cancers (21-23), adenovi- 
ral vectors containing the DF3/MUC1 promoter could be used in these settings to further increase selectivity of gene transduction. Alternatively, other tumor-selective DNA regulatory elements can be used in a similar context. The present results support the use of replication defective adenoviral vectors with the DF3/MUC1 promoter for purging hematopoietic cell preparations in the clinical setting.

\section{Acknowledgments}

This investigation was supported by the Department of the Army, grant \#DAMD 17-94-J-4394. The content of the information does not necessarily reflect the position or the policy of the government, and no official endorsement should be inferred.

\section{References}

1. Peters, W.P., E.J. Shpall, R.B. Jones, G.A. Olsen, R.C. Bast, J.P. Gockerman, and J.O. Moore. 1988. High-dose combination alkylating agents with bone marrow support as initial treatment for metastatic breast cancer. J. Clin. Oncol. 6:1368-1376

2. Kennedy, M.J., R.A. Beveridge, S.D. Rowley, G.B. Gordon, M.D. Abeloff, and N.E. Davidson. 1991. High-dose chemotherapy with reinfusion of purged autologous bone marrow following dose-intense induction as initial therapy for metastatic breast cancer. J. Natl. Cancer Inst. 83:920-926.

3. Antman, K., L. Ayash, A. Elias, C. Wheeler, M. Hunt, J.P. Eder, B.A. Teicher, J. Critchlow, J. Bibbo, L.E. Schnipper, et al. 1992. A phase II study of high-dose cyclophosphamide, thiotepa, and carboplatin with autologous marrow support in women with measurable advanced breast cancer responding to standard-dose therapy. J. Clin. Oncol. 10:102-110.

4. Peters, W.P., M. Ross, J.J. Vredenburgh, B. Meisenberg, L.B. Marks, E. Winer, J. Kurtzberg, R.C. Bast, Jr., R. Jones, E. Shpall, et al. 1993. High-dose chemotherapy and autologous bone marrow support as consolidation after standard-dose adjuvant therapy for high-risk primary breast cancer. J. Clin. Oncol. 11:1132-1143.

5. Ross, A.A., B.W. Cooper, H.M. Lazarus, W. Mackay, T.J. Moss, N. Ciobanu, M.S. Tallman, M.J. Kennedy, N.E. Davidson, D. Sweet, et al. 1993. Detection and viability of tumor cells in peripheral blood stem cell collections from breast cancer patients using immunocytochemical and clonogenic assay techniques. Blood. 82:2605-1210.

6. Cote, R.J., P.P. Rosen, M.L. Lesser, L.J. Old, and M.P. Osborne. 1991. Prediction of early relapse in patients with operable breast cancer by detection of occult bone marrow micrometastases. J. Clin. Oncol. 9:1749-1756.

7. Diel, I.J., M. Kaufmann, R. Goerner, S.D. Costa, S. Kaul, and G. Bastert. 1992. Detection of tumor cells in bone marrow of patients with primary breast cancer: a prognostic factor for distant metastasis. J. Clin. Oncol. 10:1234-1539.

8. Molino, A., M. Colombatti, F. Bonetti, M. Zardini, F. Pasini, A. Perini, G. Pelosi, G. Tridente, D. Veneri, and G.L. Cetto. 1991. A comparative analysis of three different techniques for the detection of breast cancer cells in bone marrow. Cancer. 67:1033-1036.

9. Simpson, S.J., M. Vachula, M.J. Kennedy, H. Kaizer, J.S. Coon, R. Ghalie, S. Williams, and D. Van Epps. 1995. Detection of tumor cells in the bone marrow, peripheral blood, and apheresis products of breast cancer patients using flow cytometry. Exp. Hematol. 23:1062-1068.

10. Datta, Y.H., P.T. Adams, W.R. Drobyski, S.P. Ethier, V.H. Terry, and M.S. Roth. 1994. Sensitive detection of occult breast cancer by the reverse-transcriptase polymerase chain reaction. J. Clin. Oncol. 12:475-482.

11. Gerhard, M., H. Juhl, H. Kalthoff, H.W. Schreiber, C. Wagener, and M. Neumaier. 1994. Specific detection of carcinoembryonic antigen-expressing tumor cells in bone marrow aspirates by polymerase chain reaction. J. Clin. Oncol. $12: 725-729$.

12. Anderson, I.C., E.J. Shpall, D.S. Leslie, K. Nustad, J. Ugelstad, W.P. Peters, and R.C. Bast, Jr. 1989. Elimination of malignant clonogenic breast cancer cells from human bone marrow. Cancer Res. 49:4659-4664.

13. Tondini, C., S.A. Pap, D.F. Hayes, A.D. Elias, and D.W. Kufe. 1990. Evaluation of monoclonal antibody DF3 conjugated wtih ricin as a specific immunotoxin for in vitro purging of human bone marrow. Cancer Res. 50:11701175 .

14. Shpall, E.J., R.C. Bast, Jr., W.T. Joines, R.B. Jones, I. Anderson, C. Johnston, S. Eggleston, M. Tepperberg, S. Edwards, and W.P. Peters. 1991. Immunomagnetic purging of breast cancer from bone marrow for autologous transplantation. Bone Marrow Transplant. 7:145-151.

15. Shpall, E.J., R.B. Jones, R.C. Bast, Jr., G.L. Rosner, R. Vandermark, M. Ross, M.L. Affronti, C. Johnston, S. Eggleston, M. Tepperburg, et al. 1991. 4-hydroperoxycyclophosphamide purging of breast cancer from the mononuclear cell fraction of bone marrow in patients receiving high-dose chemotherapy and autologous marrow support: a phase I trial. J. Clin. Oncol. 9:85-93.
16. Myklebust, A.T., A. Godal, S. Juell, A. Pharo, and O. Fodstad. 1994. Comparison of two antibody-based methods for elimination of breast cancer cells from human bone marrow. Cancer Res. 54:209-214.

17. Passos-Coelho, J., A.A. Ross, J.M. Davis, A.M. Huelskamp, B. Clarke, S.J. Noga, N.E. Davidson, and M.J. Kennedy. 1994. Bone marrow micrometastases in chemotherapy-responsive advanced breast cancer: effect of ex vivo purging with 4-hydroperoxycyclophosphamide. Cancer Res. 54:2366-2371.

18. Graham, F.L., J. Smiley, W.C. Russel, and R. Nairn. 1977. Characteristics of a human cell line transformed by DNA from human adenovirus type 5.J. Gen. Virol. 36:59-72.

19. Manome, Y., M. Abe, M.F. Hagen, H.A. Fine, and D.W. Kufe. 1994. Enhancer sequences of the DF3 gene regulate expression of the herpes simplex virus thymidine kinase gene and confer sensitivity of human breast cancer cells to ganciclovir. Cancer Res. 54:5408-5413.

20. Chen, L., D. Chen, Y. Manome, Y. Dong, H.A. Fine, and D.W. Kufe. 1995. Breast cancer selective gene expression and therapy mediated by recombinant adenoviruses containing the DF3/MUC1 promoter. J. Clin. Invest. 96 $2775-2782$.

21. Kufe, D., G. Inghirami, M. Abe, D. Hayes, H. Justi-Wheeler, and J. Schlom. 1984. Differential reactivity of a novel monoclonal antibody (DF3) with human malignant versus benign breast tumors. Hybridoma. 3:223-232.

22. Friedman, E.L., D.G. Hayes, and D.W. Kufe. 1986. Reactivity of monoclonal antibody DF3 with a high molecular weight antigen expressed in human ovarian carcinomas. Cancer Res. 46:5189-5194.

23. Maimonis, P., D. Hayes, C. O'Hara, and D. Kufe. 1990. Detection and characterization of a high molecular weight lung carcinoma-associated antigen. Cancer Res. 50:6738-6743.

24. Sutherland, H.J., P.M. Lansdorp, D.H. Henkelman, A.C. Eaves, and C.J. Eaves. 1990. Functional characterization of individual human hematopoietic stem cells cultured at limiting dilution on supportive marrow stromal layers. Proc. Natl. Acad. Sci. USA. 87:3584-3588.

25. Pasqualini, R., J. Bodorova, S. Ye, and M.E. Hemler. 1993. A study of the structure, function and distribution of $\beta_{5}$ integrins using novel anti- $\beta_{5}$ monoclonal antibodies. J. Cell Sci. 105:101-111.

26. Herz, J., and R.D. Gerard. 1993. Adenovirus-mediated transfer of low density lipoprotein receptor gene acutely accelerates cholesterol clearance in normal mice. Proc. Natl. Acad. Sci. USA. 90:2812-2816.

27. Abe, M., and D. Kufe. 1993. Characterization of cis-acting elements regulating transcription of the human DF3 breast carcinoma-associated antigen (MUC1) gene. Proc. Natl. Acad. Sci. USA. 90:282-286.

28. Graham, F.L., and L. Prevec. 1991. Manipulation of adenovirus vectors. In Methods in Molecular Biology: Gene Transfer and Expression Protocols. E.J. Murray, editor. The Humana Press, Inc., Clifton, N.J. 109-128.

29. Jain, V.K., and I.T. Magrath. 1991. A chemiluminescent assay for quantitation of beta-galactosidase in the femtogram range: application to quantitation of beta-galactosidase in lacZ-transfected cells. Anal. Biochem. 199:119-124.

30. Nolan, G.P., S. Fiering, J.F. Nicolas, and L.A. Herzenberg. 1988. Fluorescence-activated cell analysis and sorting of viable mammalian cells based on beta-D-galactosidase activity after transduction of Escherichia coli lacZ. Proc. Natl. Acad. Sci. USA. 85:2603-2607.

31. Taswell, C. 1981. Limiting dilution assays for the determination of immunocompetent cell frequencies. I. Data analysis. J. Immunol. 126:1614-1619.

32. Nolta, J.A., E.M. Smogorzewska, and D.B. Kohn. 1995. Analysis of optimal conditions for retroviral-mediated transduction of primitive human hematopoietic cells. Blood. 86:101-110.

33. Zhang, W.W., P.E. Koch, and J.A. Roth. 1995. Detection of wild-type contamination in a recombinant adenoviral preparation by PCR. Biotechniques. 18:444-447.

34. Steel, R.G.D., and J.H. Torrie. 1960. Principles and Procedures of Statistics with Special Reference to the Biological Sciences. McGraw-Hill Book Co. New York. 1-481.

35. Mathias, P., T. Wickham, M. Moore, and G. Nemerow. 1994. Multiple adenovirus serotypes use alpha $\mathrm{v}$ integrins for infection. J. Virol. 68:6811-6814.

36. Wickham, T.J., P. Mathias, D.A. Cheresh, and G.R. Nemerow. 1993. Integrins alpha v beta 3 and alpha v beta 5 promote adenovirus internalization but not virus attachment. Cell. 73:309-319.

37. Wu, G.Y., and C.H. Wu. 1988. Receptor-mediated gene delivery and expression in vivo. J. Biol. Chem. 263:14621-14624.

38. Wu, G.Y., J.M. Wilson, F. Shalaby, M. Grossman, D.A. Shafritz, and C.H. Wu. 1991. Receptor-mediated gene delivery in vivo. Partial correction of genetic analbuminemia in Nagase rats. J. Biol. Chem. 266:14338-14342.

39. Nabel, E.G., G. Plautz, and G.J. Nabel. 1990. Site-specific gene expression in vivo by direct gene transfer into the arterial wall. Science (Wash. DC). 249:1285-1288.

40. Nabel, E.G., D. Gordon, Z.Y. Yang, L. Xu, H. San, G.E. Plautz, B.Y. Wu, X. Gao, L. Huang, and G.J. Nabel. 1992. Gene transfer in vivo with DNAliposome complexes: lack of autoimmunity and gonadal localization. Hum. Gene Ther. 3:649-656.

41. Seth, P., U. Brinkmann, G.N. Schwartz, D. Katayose, R. Gress, I. Pastan, and K. Cowan. 1996. Adenovirus-mediated gene transfer to human breast tumor cells: an approach for cancer gene therapy and bone marrow purging. Cancer Res. 56:1346-1351. 
42. Vile, R.G., and I.R. Hart. 1993. In vitro and in vivo targeting of gene expression to melanoma cells. Cancer Res. 53:962-967.

43. Vile, R.G., and I.R. Hart. 1993. Use of tissue-specific expression of the herpes simplex virus thymidine kinase gene to inhibit growth of established murine melanomas following direct intratumoral injection of DNA. Cancer Res. 53:3860-3864.

44. Huber, B.E., C.A. Richards, and T.A. Krenitsky. 1991. Retroviral-mediated gene therapy for the treatment of hepatocellular carcinoma: an innovative approach for cancer therapy. Proc. Natl. Acad. Sci. USA. 88:8039-8043.
45. Harris, J.D., A.A. Gutierrez, H.C. Hurst, K. Sikora, and N.R. Lemoine. 1994. Gene therapy for cancer using tumor-specific prodrug activation. Gene Therapy. 1:170-175.

46. Clarke, M.F., I.J. Apel, M.A. Benedict, P.G. Eipers, V. Sumantran, M. Gonzalez-Garcia, M. Doedens, N. Fukunaga, B. Davidson, J.E. Dick, et al. 1995. A recombinant bcl- $x_{\varsigma}$ adenovirus selectively induces apoptosis in cancer cells but not in normal bone marrow cells. Proc. Natl. Acad. Sci. USA. 92: 11024-11028. 